To cite use Rogers, C (forthcoming), "Life Stories, Criminal Justice and Caring Research." In G, Noblit. [Ed] Oxford Research Encyclopedia of Education, New York, Oxford University Press.

\title{
Life Stories, Criminal Justice and Caring Research
}

\section{Chrissie Rogers}

Summary In the context of offenders who have learning difficulties, autism and/or social, emotional and mental health problems, their families, and professionals who work with them, I explore caring and ethical research processes via fieldnotes I wrote while carrying out lifestory interviews. Life-story interviews and recording fieldnotes within qualitative criminological, education and sociological research have long since been used to document and analyse communities, institutions and everyday life in the private and public spheres. They richly tell us about specific contexts, research relationships and emotional responses to data collection that interview transcripts alone overlook. It is in the process of recording and reflecting upon research relationships that we can see and understand 'care-full' research. But caring and ethical research works in an interdependent and relational way. Therefore, the participant and the researcher are at times vulnerable, and recognition of such is critical in considering meaningful and healthy research practices. However, the acknowledgment that particular types of data collection can be messy, chaotic and emotional is necessary in understanding caring research.

Keywords Autism, care ethics model, criminal justice, feminist ethics of care, fieldnotes, learning disabilities/difficulties, life stories, mothering,

\section{Introduction}

The use of fieldnotes, and documenting life has long since been an integral part of doing qualitative criminological, education and sociological research (e.g. Becker [1963] 1991, Kelly 1988, Plummer 1995, Whyte [1943] 1993, Willis, [1978] 1997). Certainly, within the Chicago School, Feminist and Marxist traditions, positioning the researcher on the side of marginalised and misrepresented groups and individuals was often core to the study of social behaviour and oppression as presented for example, in Becker's (1967) discussions about 'whose side are we on?', Kelly's (1988) stories of surviving sexual violence, and Oliver (1990) and Morris' (1991) studies around disability politics and practices. Perhaps not much has changed, as life-story and qualitative narratives about criminal (in)justice and education continue (Condry 2007, Fassin 2017, Fish 2018, Gillies 2016, Rogers 2007, 2016). Moreover, when carrying out such emotive research there are dilemmas, quandaries, silences and secrets (Cowburn et al. 2017, Gillies and Robinson 2010, Ribbens and Edwards 1998, Rogers and Ludhra 2012, Ryan-Flood and Gill 2010), yet doing research care-fully is critical, for all parties involved. Therefore, as a result of collecting life-story narratives about criminal (in)justice, education pathways, mothering, and abuse (physical, emotional and systemic), I paint a picture via fieldnotes so as to explore caring research. However, unlike many reflections on methods processes, rather than mapping a 'how to do' research, I lay bare the 'doing of' qualitative criminological research, as an aid to think through research challenges. As well as to question at a deeper and honest level, if qualitative research is ever completely care-full and without repercussions for all involved. Nevertheless, not doing research because there are ethical challenges, because it is 
To cite use Rogers, C (forthcoming), "Life Stories, Criminal Justice and Caring Research." In G, Noblit. [Ed] Oxford Research Encyclopedia of Education, New York, Oxford University Press.

emotionally and practically messy, chaotic, puzzling and time consuming and, for fear of getting it wrong, is unjust. As researchers, ought we recoil at ways of doing research because it feels uncomfortable? No, we ought not, as to recognise sensitivities around criminological, sociological and education research is not necessarily to constrain or curtail exploring a subject, it does, however, present challenges which, when thought through, can produce richer data' (Cowburn et al, 2017: 221).

\section{A care ethics model - doing caring research}

A feminist ethics of care critiques established ways of thinking about ethics, compassion, morality, citizenship, security, and care (e.g., Gilligan 1993, Held 2006, Noddings 2003, Robinson 2011, Tronto 2011). It is within this context a care ethics model of disability (Rogers, 2016) interrogates political and relational implications, yet specifically draws from caring and ethical relations. A care ethics model of disability (and the care-full spaces that are within it), is about trust and webs of relationships. It focuses on both the receiver and the giver of care. In this case the researcher and researched. As it is human beings live together, regardless of their intellectual capacity, relationally and with reciprocity. It is worth reflecting upon this within the context of caring research. Furthermore, Arendt (1998: 7) says ' $[n]$ o human life, not even the life of a hermit in nature's wilderness, is possible without a world which directly or indirectly testifies to the presence of other human beings' (ibid, 22). My previous work (Rogers, 2016) states that disabled people who have learning difficulties and/or 'challenging behaviours' are at the bottom of the human hierarchy and are often considered to have little worth. This is especially as it is assumed many are unable to contribute to society economically and politically, due to an intellectual impairment, and/or experiencing social, emotional and mental health (SEMH) problems. If an individual has these stigmas, but has also, for example, committed acts of violence, sexual assault/harassment, arson, drug handling/dealing and theft, or is a mother to such a person, it can result in being doubly damned, experiencing worthlessness at best. Therefore, theoretically this essay draws upon a care ethics model of disability that includes justice-based positions to understand social divisions, injustice and everyday experiences (Rogers 2016), that reside both in the substantive area of research and the data collection processes. As it is, I developed a care ethics model of disability in response to the continued de-humanisation of intellectually disabled people (Rogers 2016). It is within this theoretical context, and in engaging with fieldnotes I explore care-full research practices. Largely because an 'ethics of care that is political and critical must be grounded in the concrete activities of real people in the context of social relations' (Mahon and Robinson 2011: 2). Moreover, home, school and prison life, is influenced by the macro and micro politics of bureaucratic systems, that are increasingly restrictive and bounded and do not promote caring relations.

To understand this framework further, and in relation to methods, a care ethics model of disability (Rogers 2016: 2) proposes three spheres of caring. The Emotional Caring Sphere, where love and care are psycho-socially questioned; The Practical Caring Sphere, where day to day care is carried out relationally, and The Socio-political Caring Sphere, where social intolerance and aversion to difficult differences are played out. I propose these spheres are often populated with many care-less spaces. They also interact in complex ways and are grounded in social and political relations that seek caring legal and cultural processes (Rogers 2016). At the very least I suggest a need to challenge socio-political processes across institutions that trouble us. This can be identified for example in education, via Val Gillies' 
To cite use Rogers, C (forthcoming), "Life Stories, Criminal Justice and Caring Research." In G, Noblit. [Ed] Oxford Research Encyclopedia of Education, New York, Oxford University Press.

(2016: 181) research on inclusion and behaviour support. She found disadvantaged children and young people,

are removed to the periphery of school ostensibly to undergo rehabilitative interventions to address fundamental personal deficits. The effect is to surreptitiously remove entitlement to mainstream education while reapportioning blame for attainment gaps, away from schools onto parents and young people themselves. Troublesome difference and learning difficulties are identified, diagnosed and isolated from the important business of curriculum learning. Meanwhile, the risk lens applied to those contained within the units extends the purview of criminal justice services, compounding risky trajectories.

Therefore, a care ethics model of disability is 'not about individual rights and freedom, as this detracts from the politics of care and leads us to a paternalistic state of doing and being, where those who are considered more vulnerable, frail and dependent are placed in a powerless position' (Rogers 2016: 34), but, that it is about human flourishing and social relations. With this at the heart of conducting life-stories, caring and ethical research ought to be pursued.

\section{Reflecting upon fieldnotes}

Considering life-story and caring research I reflect upon fieldnotes because they expose a range of emotional and practical responses to a chaotic data collection process, and more often a moment in time. A moment that perhaps is continuous and bound up with the micro-politics of a domestic environment and embedded in the socio-political sphere of the criminal justice system (CJS). Moreover, it identifies a process that is often wrought with ethical dilemmas and personal costs, where moral judgements are conceivably suspended, and blurred boundaries might occur. Notes scribbled here after my first life-story interviews with both a mother and her son identify some of these issues. I had no idea of what was to come but remaining unnerved was perhaps important.

I walked into her house. It was lived in. Lots of stuff around and a strong smell of cigarette smoke filled my nostrils. She seemed a little anxious and had a slightly haunted look about her, and yet greeted me with such a warmth. I like her, my first Mum. Then her 22-year-old son wandered in. He'd been in prison for a sex offence and arson. I didn't expect him to be there. We hadn't arranged it. It was a surprise. I had however, previously asked, if she thought he would want to be interviewed, but she had said, 'no he didn't'. So now he wanted to talk to me. They both sat down on the sofa and it was all a bit strange, as I said to them both, 'perhaps you can be interviewed separately?' They had this strained conversation about who was going first. Anyway, we did end up doing the interviews separately. I started the interview with Mum and her son wandered into the lounge and said, 'where's the axe?!' Apparently, he wanted to chop some wood in the garden. Who knew? Then after being in the garden, and having cut his finger, he walked past with a knife; not a kitchen knife, but one in a sheath. I mean he's 22 , been in 'special' schools, got mental health problems, not been out of prison that long, and he now wanted to be interviewed. I had said 'okay', but I hadn't planned for it at this time. I also didn't know if the axe and knife business were for effect, to provoke a reaction. Perhaps if a social worker or probation officer, someone else, perhaps they might have said something? But I didn't. I didn't bat an eyelid, I mean what am I going to say? 'What are you going to do with that knife?' To be perfectly honest, I didn't feel in any danger. After both interviews and now into the 
To cite use Rogers, C (forthcoming), "Life Stories, Criminal Justice and Caring Research." In G, Noblit. [Ed] Oxford Research Encyclopedia of Education, New York, Oxford University Press.

evening, Mum offered me dinner and a big hug. I took the hug but declined dinner. It was getting late. Besides I had a long drive ahead of me. (Fieldnotes -Autumn 2016).

My voice in this excerpt is clear, but my reflection is somewhat questioning, even agitated. I highlight this one, to begin, because it underlines the adaptability and inter-personal interaction that is required in caring research, as researchers ought to know that carrying out a life-story interview, however much it is planned, can change, at the toss of a coin. As it is, the voice of a researcher, in this case mine, is sometimes explicit in the telling of a story, and often within qualitative research we 'are inside social life. [...] and that's where we get our oxygen from' (Worley et al., 2016: 299). This is the case for me, as I breathe and look for social justice in a 'caring' research process.

In the following section I contextualise the specific field within criminal justice research and my observations that ground the study. The section after that presents an account of the motivation for my research and the following two sections explore gaining access to the field. I then go on to describe the actual data collection, which is often the place where descriptions of a method process begin. The penultimate section examines the emotional and subject content of such life-story interviews that can fracture and contaminate yet refine and support a challenging research journey. I then conclude, reflecting upon a care ethics model and methodological processes.

\section{Contextualising the Subject: Learning Difficulties (LD), Social Emotional and Mental Health (SEMH) and Criminal Justice}

Prisons and their inmates are commonly reported in the news media, with stories about riots, squalor, drugs, self-harm and suicide hitting the headlines. Prisoner families are left to worry about the implications of such events on their kin, while those less able to understand social cues, norms and rules are left vulnerable to deteriorating mental health at best, to die at worst (Codd 2008, Condry 2007, Talbot 2010). Whilst prison riots and discontent are not simply a 21st Century problem (Carrabine 2005, Jewkes et al. 2016), the rise in prisoner numbers, combined with persistent news coverage of prisoner unease, violent conflict and suicides, is a growing concern. Perhaps all of this is unsurprising, as Helen Codd said about prisons, 'they are brutalising places and even if you don't go in with a mental disorder, you're quite likely to come out with one' (2016: 22). Therefore, offenders who have learning difficulties (LD), are on the autism spectrum (AS), and/or experience social, emotional and mental health (SEMH) problems, face challenges that the early $21^{\text {st }}$ Century criminal justice process in the UK simply fuels. Moreover, their parents/carers, who have been through varying levels of conflict in all spheres of life, then face not only hearing about the criminal justice landscape via various social media portals, they also experience their own level of imprisonment, vicariously, as emotional responses to fear, blame, shame, loss, sleeplessness and the unknown occur.

The research process and substantive areas highlighted here are grounded upon several observations. First, best available estimates suggest that $30 \%$ of prisoners in the UK have a learning difficulty or disability (Talbot, 2010), implying the existence of many potentially vulnerable and marginalised prisoners who experience varying degrees of difficulty in negotiating prison rules and norms. In addition, Hughes and his colleagues found a prevalence 
To cite use Rogers, C (forthcoming), "Life Stories, Criminal Justice and Caring Research." In G, Noblit. [Ed] Oxford Research Encyclopedia of Education, New York, Oxford University Press.

of neuro-disability amongst young people who offend (Hughes et al. 2012). Second, despite strong evidence that the effects of school exclusions on offending and incarceration risk, (sometimes bound up with 'looked after' children (Laming, 2016)), and that offenders with SEMH and/or LD struggle to cope with prison, there is limited in-depth research on how this disadvantage shapes their offending behaviour, prison experience and education pathway (Gillies 2016, Gillies and Robinson, 2013, Hayes et al. 2007, Wadhwa 2016). In many cases, caring work that goes on during the schooling years and beyond is exhausting, for health and education professionals, as well as families/carers, and yet not enough is being done about one of the most challenging 'dirty little secrets' in education; 'the role special education plays in creating a class of students who are more suited for prison than for college' (Clemson 2015: 43). All the while there are problems within education and how these difficult differences are dealt with, students will be lost along the school-to-prison pipeline, impacting negatively upon parents (namely mothers ${ }^{\mathrm{i}}$ ), who are often trying to keep the family afloat, and education professionals who are not only dealing with teaching, but become quasi social and family liaison workers. 'Only by keeping careful track of the movements of all students - and by devising policy and incentives geared toward plugging up a leaky pipeline - will we make progress in transforming a school-to-prison pipeline into a journey toward hope and opportunity' (Wald and Losen 2007: 35).

Third, state actors typically make decisions regarding prison regimes and populations based on unspoken assumptions around rationality, language, and mental capacity which is consequential for the experience of offenders with SEMH and/or LD and their families (Jewkes et al 2016). And finally, personal reflections and past research within the areas of LD/SEMH, education and mothering, inform me that injustices transpire and not enough is being done to support an already challenging process for offenders and their families (Rogers, 2007, 2011, 2016). In short, in contrast to other disadvantaged people, prisoners with SEMH and/or LD, and their families/carers, have received less scholarly attention than their risk of criminalisation and experience of the prison system arguably merits. For example, 'punishment extends beyond prison walls and reaches into every facet of these families' lives', (Condry et al 2016: 625) and all concerned can feel stigmatisation by association (Codd 2008 2016, Comfort 2008). Therefore, rather than a blame narrative, whether it is the 'dysfunctional family' or the 'deficit child', we require ethically just and care-full practices as a fundamental part of interrogating the socio-political sphere - which includes education and legal systems.

Based on these observations and access gained, I have;

1. Explored the life story experiences of people with SEMH and/or LD who have been through the criminal justice system.

2. Explored the life story experiences of mothers who have a family member as above. (Only mothers came forward).

3. Examined how offenders and/or their families make sense of, and cope with the criminal justice process, prison culture, routines, rules, and practices, and how this impacts on all their lives on release.

4. Investigated the pre-criminal pathways, for example, a 'school to prison' pipeline, and childhood/family support practices. 
To cite use Rogers, C (forthcoming), "Life Stories, Criminal Justice and Caring Research." In G, Noblit. [Ed] Oxford Research Encyclopedia of Education, New York, Oxford University Press.

The research discussed below ultimately moves past risk-based approaches to offending and reoffending by examining emotional responses to experiences of the CJS and incarceration that go beyond the crimes committed and into the data collections sphere. Yet talking about the crime is still evidently necessary, as it plays a part in how, for example, personal and maternal experiences pan out, how offenders experience stigmas such as being labelled a sex offender, drug addict or as violent, and then how I as a researcher, respond to such narratives. It is the latter I investigate for the purposes here, and explore a care ethics model of disability to understand caring research

By exploring everyday experiences via three caring spheres; the emotional, practical, and socio-political, my care ethics model can provide an analytically powerful framework for examining the social and political relations that shape the interface of disability, education, mental health, criminalisation, criminal justice, incarceration and mothering/caring as a social process rather than a series of loosely connected events (Rogers, 2016). By contemplating the subject matter, we can recognise the sensitivity of the research context while carrying out research.

\section{Motivation for the Research}

Like with any project, to consider the motivation for the study and how the process begins is sometimes as important as how the research develops, especially because this groundwork is vital in doing caring and ethical research (Rogers and Ludhra 2012). This is particularly evident if assumptions are made about gaining access in the first instance. That was perhaps my first hurdle, as my previous research had not focussed on criminal justice, and yet as a sociologist who has written about learning difficulties and challenging behaviours in the context of education, mothering, and intimacy, it made sense to explore another avenue of injustice. Largely because it was during my $\mathrm{PhD}$ research, where the focus was to examine the in-depth and everyday experiences of parenting a child identified with 'special educational needs', several mothers spoke about how their young son's behaviour was sometimes challenging. For example, Lynne told me, '[h]e was touching girls in assembly [...] he didn't seem able to stop it, I mean he didn't rape anybody but, [...] he was saying sexual things to them, so anyway he got suspended', her 14-year-old son then spent a year at home, having nowhere to go, but home tuition (Rogers, 2007:75). Later, in the interview, Lynne exclaimed that when her son was suspended for inappropriate sexual behaviour, 'I was just about suicidal' (ibid: 152), evidencing the depth of emotional and practical impact felt from such experiences, not just in this instance, but as a constant concern. Tracy, another mother, talked to me about two of her sons, both of whom had different, but challenging conditions. I had not written about her sons' sexualised behaviour before, yet when I went back to the raw data a few years later, I found that Tracy expressed,

(there were) possible sexual undertones with the younger girls, but I think what his body was saying 'hey I've got lots of hormones' (pause) this was when he was about 14,15 and 'I've got lots of hormones here I'm a man' but mentally he relates better to smaller children because of his mental age, and he made friends with a little girl [...] and he used to play with her and tickle her and (pause) although nobody ever said that he'd touched her sexually (pause) because of his size, and looking like a full grown man (it was) inappropriate for him to be playing with a 7, 8 year old girl' (Rogers, 2016: 107) 
To cite use Rogers, C (forthcoming), "Life Stories, Criminal Justice and Caring Research." In G, Noblit. [Ed] Oxford Research Encyclopedia of Education, New York, Oxford University Press.

Tracy also told me her younger son, at the age of 6 , had set fire to a 'portable' classroom at school and was then permanently excluded from school, he used to 'escape' by any means he could from the house, and he had stolen money from teachers. She went on to say that when he was a little older he threw knives at her and had threatened to kill the babysitter. At this point, Tracy said 'the social services were a complete waste of space' (Rogers, 2016: 107), as she had told them time and time again about her struggles with her sons.

When reflecting upon her challenges Tracy displayed a narrative of hope at that time, perhaps not in the way we might think, but that she hoped neither would commit a serious violent or sexual crime, despite contemplating their possible and almost inevitable future life as a criminal. Many mothers have hopes for their child's future, but for some, as in the narratives below, they are 'ruptured, tainted, if not ruined' (Rogers, 2016: 99) (see also Condry 2007, Condry et al. 2016). As it was with Tracy, one of her sons spent time in locked institutions, (residential schools) miles away from her home, and the other one, more recently, had spells in prison over the past few years. Critically, because I had a connection with Tracy - I had carried out life-story interviews with her in 2002 and 2003, and I was an acquaintance to her sister - I assumed she would willingly take part in my criminal justice research. Tracy endured persistent emotional trauma with her sons, and the desire to move forward with her life meant she did not want to be interviewed as the recall of memories was too horrific.

I also quickly recognised Tracy was not the only mother unable to speak about her prisoner family experience. As in my criminal justice research, one mother on Twitter contacted me when she saw my research advert for participants online. Her 26-year-old autistic son with a dual diagnosis was in prison. She wanted to tell her story but could not bring herself to go ahead with an interview because 'it was too difficult'. It is clear in my field notes that I was struggling as the researcher, because although there was interest, it did not amount to participant interviews as evidenced here,

I've tweeted, emailed, contacted potential gate-keepers. Been in touch with charities, it was quiet, 'it's oh so quiet', as Bjork sang in her song of the same name. Yes quiet, and then CRAZY. But the craziness is interest, not actual participants. That takes time. I feel this scattergun approach, firing down all avenues feels uncomfortable. I'm ill-atease. No control over what happens next. It feels like doing a $\mathrm{PhD}$, but in on fast forward, quick time; it feels, just feels. I wonder how I'm going to manage. This is not an easy group to get hold of (Fieldnotes, August 2016).

I probably, at that point, began to realise communicating on social media, for a number of potential participants was different to opening up to a person face to face. As some of my participants have said, telling their life-story brings things to the fore memories and feelings that are painful and traumatic. I wonder if this is care-full: the facilitation of such raw emotions? The cost of not doing sensitive research, and therefore not inciting change, is arguably more damaging (see also Turner and Almack 2017).

\section{Gaining and Maintaining Access}

I struggled to gain access to both offenders with learning difficulties and family members and so had to adapt my focus early on. I needed to find someone to talk to me, and therefore looked to professionals who worked in the learning disability forensic setting, or in education. I also had potential participants want to talk to me who had either a dual diagnosis or a past/current 
To cite use Rogers, C (forthcoming), "Life Stories, Criminal Justice and Caring Research." In G, Noblit. [Ed] Oxford Research Encyclopedia of Education, New York, Oxford University Press.

mental health problem. Therefore, not quite fitting the learning difficulty brief. I recognised the importance of this criminal justice research even more and adapted as I demonstrate below.

I made lots of phone calls, trying to source participants and make relevant links to the charities and individuals and so on. This is hard. I have to look for professionals who work in the forensic setting, or in the education that deals with challenging young people. I'm struggling to get any ex-offenders and am worried I will fall at the first hurdle. For example, those I wanted, those with learning difficulties seem to be incredibly difficult to find, due to all sorts of reasons, not least, how do I find them? They are often not online or do not have the necessary skill set to engage online. But there are other reasons too. One professional who works in the community with exoffenders who have LD/SEMH said, 'I have asked some of our clients about this type of research and being interviewed and they said they had "moved on". He told me, "to quote one young man, "that was then, why the fuck would I want to talk to anyone now, dredging it all up? Anyway, who wants to know?"' He told me he tried to explain to the lads he worked with that "it was for the greater good, and that we could all learn from it". That didn't work'. I begin to realise that getting hold of offenders, getting hold of families, getting hold of anyone is going to be tricky. I'm worried! (Fieldnotes, Autumn, 2016).

In the first couple of months of a research project, questions one might ask are, 'will I get participants and how will their stories play out?' But many of us do not immediately think of the stuff that goes on before the data collection, beyond the data collection and underneath the data collection. Yet no end of preparation, missed opportunities and groundwork occur as I suggest here.

Sitting at a disability studies conference, I reflect on the first few weeks of my research. It can only be described as crazy. The UNLOCK mail shot, and a few other contacts for now, have paid off. I feel utterly overwhelmed with the attempt at trying to organise different types of people. Then people say yes, they want to be involved, but then after we've arranged a time, they don't get back to me and that's after we have communicated on various occasions. It's especially difficult when these are not close by, not in any way local to me geographically. I'm not sleeping quite as well - but I guess that could be anything! It all feels quite messy. Not on brief completely. I must go on. I don't want to turn people away as their stories matter, and they have bothered to respond to me. I want to tell their story. Snowballing has begun, and about that on brief thing, if I had said no to this one participant because she didn't 'fit' within the learning difficulty bracket, I would not have another who does. The way I feel right now? It is so important to be open, to be flexible, to be adaptable (Fieldnotes - Autumn, 2016).

In only the first few weeks of the research process, these excerpts from my fieldnotes, gained via handwritten scribbles and voice recorded reflections share with the reader a glimpse into what is going on before any significant data collection is collected, and yet the impact upon me as the researcher, the participants who have come forward and yet not been interviewed, and upon the whole process is obvious in this excerpt.

I was going to see an ex-offender, a woman, and we had email communication, several. We set a date, she seemed genuinely interested and enthusiastic. We had emailed the day before the arranged interview date and then on the day nothing. I had a date, but 
To cite use Rogers, C (forthcoming), "Life Stories, Criminal Justice and Caring Research." In G, Noblit. [Ed] Oxford Research Encyclopedia of Education, New York, Oxford University Press.

she had not responded with where to meet. I emailed several times on the day, but nothing. I clearly could not meet her without a place. The next day I emailed saying 'I hoped she was okay, and not to worry. We can re-schedule', or 'if you've changed your mind don't worry'. Still nothing. I emailed once more a few days later, and then thought I better leave her alone. She never got back to me. [...] Then I had another cancellation! We had already re-scheduled once. I drove all the way from Glasgow to Yorkshire and sat outside her house. I had spoken to her on the phone, the night before, with me saying 'I'm driving a long way', and was she 'still okay with me coming?' I rang her while sitting outside her house. Nothing. I waited for a bit but didn't want to hang around for too long as I might look out of place sitting there in my car and knocking on the door. I spoke to a neighbour and he said, 'oh she'll come back, sometime'. I figured after a while she really didn't want to be interviewed (Fieldnotes Autumn 2016).

Arguably, all this chaos, disappointment and concern is part of qualitative research and yet so often it is left out of the storytelling process. Perhaps to sanitise the research process? But do we exclude secrets and silences that emerge from a research process that might expose us as flawed or vulnerable to claim academic legitimacy? (Cooper and Rogers 2015, Ryan-Flood and Gill, 2010).

As researchers, we often say what we did, who we did it with, how we analysed the data and so on. But we do not talk about the missing data. Accessing individuals, groups or communities of people can be challenging, not least because access to certain forms of communication such as email and social media might be limited or non-existent due to personal circumstances, sanctions imposed, finances or literacy (McClimens 2007). In addition to this, the nature of the subject matter might deter potential participants to come forward, and even if they do, they might not maintain contact. What these fieldnotes tell us about this process is that some people want to tell their story, because something triggered a reason to get in touch. But on reflection, perhaps the thought of telling a stranger all about their story, especially if it is a stigmatised one of sexual assault or violence for example, becomes too much, too scary and they withdraw.

\section{Still Gaining Access}

In the early stages of gaining access, it was not simply about finding a gatekeeper, and being introduced to potential participants and then off into data collection. For me, it was about how I negotiated relationships with that gatekeeper in the first instance. They had to consider me as someone trustworthy enough to be left alone with their colleague, a service user, their family member, or a charity representative. Clearly gatekeepers have significant power, to enable access, or deny it. Particularly with children, or in this case those with learning difficulties (see also Girling 2017). I had to negotiate consent, not only with the participants, but also with those who surveyed the space and place where we all co-existed, in that moment. In one instance, after I had gained access to potential participants via a charity, I was asked to go to a meeting, to introduce myself and my research to a group of men, all whom had a learning difficulty and all who had been through the criminal justice system. This was one of their regular meetings where they discussed how and what they needed to do to make positive changes to the criminal justice system. 
To cite use Rogers, C (forthcoming), "Life Stories, Criminal Justice and Caring Research." In G, Noblit. [Ed] Oxford Research Encyclopedia of Education, New York, Oxford University Press.

This meeting was looking at criminal justice documents and how to make them more accessible. Here I talk about this early access to a particular group.

I was asked to get involved, not simply as someone who was to gain access, walk away with names and numbers in my pocket and interview at a later date, but to participate in their daylong meeting. My presentation punctuated the day somewhere in the middle; after they had met me, but before the lunch break. I was a little nervous about talking to the men, as I didn't know what to expect. That said, as someone who has worked in learning disability services many years ago and has an adult learning-disabled daughter I wasn't completely out of my comfort zone. I introduced myself, and on the first slide told them I was a university researcher and a Mum with a daughter who has learning difficulties and that she had been arrested (despite being interviewed, held in a cell and charged, her charge was later quashed due to misidentification, yet she was left traumatised for several months). I felt this was a short, but necessary part of my narrative I needed to share with them, or why would they want to talk to me? Or rather, what right have I got to walk away with their stories, without considering the interactive and relational part of this connection? I didn't want to focus on that part of my narrative, on me, but for the 12 men or so listening, it seemed an important part of their connection to me. Probably more than I realised. They were given the opportunity to ask questions and they were honest and reflective. I felt I needed to be as candid and as courteous in return. For example, we don't always get questions we expect, as evidenced here, when asked by one member in the questions and answers session, 'are you doing this to better your career?' I paused, a little taken back by the frank nature of the question, and then told them truthfully, 'perhaps that might be a positive outcome of doing the research, but that wasn't my motivation'. I relished this honesty and I think they appreciated the open discussion too (Fieldnotes, early 2017)

I introduced my research with 'easy read' slides and asked the question 'what does research mean to you?' We went on to talk about how some researchers collect numbers, and other researchers collect stories. Evidently when introducing research to potential participants, the need to consider the audience and what their requirements might be, is vital. Moreover, this is just the beginning of a potential research relationship. Reflecting upon how access is negotiated, who the audience is, and how the research is narrated ought to be part of the plan. If it is not, then arguably it is care-less and not least of all could potentially lead to nonparticipation, if not misunderstandings.

\section{Collecting the Data}

In many ways, describing the data collection is the most straightforward part of recounting research. It is where many projects start in the telling of their research story. The study 'Careless Spaces: Prisoners with learning difficulties and their families', was funded by The Leverhulme Trust. Between autumn 2016 and autumn 2017 I carried out a total of 43 in-depth life-story interviews (Plummer 2001, Ribbens and Edwards 1998). Not least because I wanted to hear stories in context, not simply listen to reflections on criminal activity, incarceration and professional life, as if these accounts are ever separated out from history and biography (Mills 1959). These interviews were with 15 adults (13 men, 2 women), who had been though the 
To cite use Rogers, C (forthcoming), "Life Stories, Criminal Justice and Caring Research." In G, Noblit. [Ed] Oxford Research Encyclopedia of Education, New York, Oxford University Press.

criminal justice process and were diagnosed with LD/ASD and/or SEMH problems, 5 mothers with sons who fit within the LD/ASD/SEMH category and 10 professionals who are/or who have worked in LD and/or SEMH forensic/education setting.

In addition, I gave all participants (excluding the professionals), a disposable camera and encouraged them to use it to record 'feelings photographs' between the first and second interview; that is if they wanted a follow-up interview. 8 of those who had offended and 4 mothers, participated in taking photographs and a follow-up interview. Some however chose to take photographs on their camera phones and send them to me via WhatsApp, and in one case, a participant wanted to photocopy his photographs and send them in the regular post, but then decided to WhatsApp me some too. All photographs were to aid our follow-up interview; to give a visual account of 'feelings', as well as facilitate discussion in a more detailed way. Notably John Berger, in the 1970s, commented 'image is a sight which has been recreated or reproduced. It is an appearance, or a set of appearances, which has been detached from the place and time in which it first made its appearance [...] every image embodies a way of seeing' (Berger, 1972: 2). Seeing is often how we make an immediate connection to something or someone, such that images in fiction, news stories, drama, art works, film and social media can shape the way people think and behave - indeed feel about things. Moreover, I agree with Jo Aldridge (2007: 13-14), when she says about eliciting photographs from people with LD,

The photographs command viewers' attention and, as the photographs have been taken by the participants themselves, they are also absorbing in a personal sense in that they provide direct insight into the experiences of those participants who have taken the picture in the first place.

It is for these reasons, and the fact that not all people with LD are able to articulate their story in any 'traditional' narrative way I chose to utilise visual methods, and more specifically participant led photographs. That said, all my participants were able to communicate their voice, their story. All follow-up interviews were based on questions I had after listening to the first interview and discussions around the photographs (see also, Copes et al. 2018).

Although these two paragraphs tell the reader what I did, it says nothing of what this involved, as in what work had to be done to get to this point, which is why the previous sections are so critical. Moreover, for my research and as a feminist, I believe Kate Hoskins captures the position of feminist qualitative research as I do, because as she says, a 'qualitative approach offers a snapshot in time; it is historically grounded and the views expressed are often fluid and subject to change as the respondents construct and reconstruct their experiences sometimes in the process of being interviewed' (2010: 136). This is particularly important for me, as participants lives seemed to change and evolve as our contact progressed - and it is not finite, even now, as I receive messages and calls to update me about their lives. For example, one participant called after his second interview (in August 2017) to let me know he did not receive a custodial sentence for a charge he was telling me about in our follow-up interview. This was a huge concern to him during that second interview and this great news he wanted to convey to me, as an interested party in his offending story, implied the development of our interdependent and arguably caring relationship (Tronto 1993, 2011). Also, three of the five mothers keep me updated about their lives and some professionals let me know the progress of certain cases they discussed in their interview. This type of research I have been carrying out is not a sanitised process and cannot be understood that way. Perhaps it is a caring one though? 
To cite use Rogers, C (forthcoming), "Life Stories, Criminal Justice and Caring Research." In G, Noblit. [Ed] Oxford Research Encyclopedia of Education, New York, Oxford University Press.

Therefore, based on this discussion, data is always 'partial and incomplete', yet is 'an insight into a story in progress rather than a final or conclusive account' (Hoskins, 2010: 136).

Significantly, the relatively small number of researchers who have carried out qualitative studies with, for example, prisoners' families offer insight into the everyday life that numbers alone cannot share. As Helen Codd reflects upon the work of Rachel Condry (2007), Megan Comfort (2008), and about her own narratives, 'the commonality of experiences and the vividness of these accounts as garnered by researchers offer far more value to someone with a genuine interest in the issues than pure numbers' (2008: 19). In my research, it is one thing to hear about how many prisoners have LD and how many families are affected, but it is another thing to hear how a mother has been at the receiving end of extreme violence from her son, or how a mother lives with the fact her son has sent vivid sexual pictures to young girls and is now on the sex offenders register. Or how a young man commits a crime simply to re-enter the criminal justice system, as that was a 'safer place', than his community, or how a number of offenders have attempted to take their own lives. For the mothers, they have in the main, cared for their sons through childhood assessments, 'special education', mental health appointments, lone parenting and chaotic education pathways. For those offender participants, they have experienced abuse, bullying, and exclusion throughout childhood and beyond. Statistics alone do not tell us about these harrowing and important stories. An interviewee's story is presented and re-presented in a particular way and at a particular point in time and it is our job as social science researchers to make sense of the data and then present and represent the participants and their lives within a particular social context and at a particular time.

\section{Ethical Considerations}

In the UK, social science research generally requires ethical approval when involving human participants (BSA 2017). In the case of my research:

- What can really be understood about offenders who have challenges related to their learning and/or mental health, mothers of this 'group' and the everyday experiences of going through the criminal justice system (CJS)?

- What claims can be made in addressing ethics for the purpose of exploring 'new' knowledge around the diverse lives of these families and individuals?

As I understand, I cannot make 'truth' claims about these people, as they are not a homogenous group. Yet, it is important to understand from the very beginning of an investigation into such areas of injustice, inequalities and social life, that doing, or at least attempting to do ethical and care-full research, is vital. As I have asked with Geeta Ludhra, (Rogers and Ludhra, 2012: 43), before, (although slightly adapted for the purposes here),

- Who voice is narrated throughout the research? The participant or the researcher?

- Who consents to the research? The gatekeeper or person with LD/SEMH?

- How included in the whole research process (from design to analysis) is the participant?

- What role do you as the researcher play, in the life of the participant and how does a relationship develop? Are you a friend, a counselor an 'objective' observer...?

There is never one easy answer to these questions, as negotiation is often key. In my research therefore, I needed to be flexible, empathetic, caring and responsive as I gained access and listened to people's life stories. As it is many 'disabled' others are excluded from being heard 
To cite use Rogers, C (forthcoming), "Life Stories, Criminal Justice and Caring Research." In G, Noblit. [Ed] Oxford Research Encyclopedia of Education, New York, Oxford University Press.

or are represented in different and sometimes negative ways, and in this research these offenders and families are amongst those most marginalised others. I did gain university ethical approval to carry out the research and all participants had the capacity to consent, but as I say above, it is a negotiated and ongoing process. No real names are used in any work I present.

\section{What Do We Do with Our 'Stuff'?}

Qualitative data can tell us about suicide attempts, drug and alcohol use, violence, criminalised sexual activity, systemic and systematic abuse as well as unconditional love and care. It could be that the events leading up to imprisonment occur as a result of, for example, an unexpected violent act, a 'one off' serious crime, a genuine mistake, or lack of understanding regarding legal boundaries, or simply continuous activities and violence that have lasted, until an arrest and a conviction is made. Nevertheless, whatever the reasons for a custodial sentence, offenders who have a LD, SEMH or ASD are at a high risk of deteriorating mental health (Talbot 2010). Moreover, often carers, parents and professionals are involved before the crime, and yet little is done about preventing the pathway to incarceration. Caring, whether in a professional or personal capacity for someone who has SEMH problems and/or a LD is demanding in ways that are often inconceivable (Rogers 2016). This is due to several factors that include, expectations around what 'typical' behaviour entails, additional practical and emotional care labour, and navigating the assessment, health and education systems. Emotional and practical care is apparent before any such criminal activity has occurred. For example, when it comes to the education system, challenges occur, and how those are dealt with are evident prior to any criminal activity (Clemson 2015, Gillies 2016). Yet crucially, it could be that more support ought to have been available to prevent incarceration.

Life-story interviews with mothers, offenders and professionals all had some 'horror' in their story telling. For example, the narratives suggest not only the continuous battle every day in and out of school for families and professionals, but also highlight the emotion work carried out. Moreover, as problems escalate, families, friends and professional others, do not always behave in ways that might be expected, desired, or needed. 'Family blaming is a persistent and powerful undercurrent in relation to the experiences of prisoners' families' (Codd, 2008: 18, see also Condry 2007). Shame, blame, loss and a lack of systematic support from friends, family and professionals working with their children, can cause emotional collapse, sometimes resulting in the reliance on anti-depressants, thoughts of suicide, and social isolation for all concerned. My job here as a researcher is not to mend their chaotic and fractured lives, as much as I would like to, but to listen: to hear what they say and attempt to make sense of it. But in that process, I do hear, and I do take on board aspects of their lives, and it does leak into my own history, biography and being (Mills 1959). I share below two fieldnotes excerpts to evidence a process of adaptability, sensitivity and caring (emotion) work.

Although it was probably an hour and a half or so into the interview before he told me about the multiple stabbing, I don't think that was intentional, to make me wait. I guess I hadn't expected that. Not sure why. I was interviewing a serious serial offender. I knew he'd been inside for a lengthy period. He showed me his self-harm scars, old, but still very visible. The big crime, he said, he feigned some remorse, but didn't feel it. He told me he only wished he'd done the job properly. The kill. I'm left with some numbness. He's such a reformed character, the bloke sitting in front of me. I'm left thinking the crime his victim committed was what? A threat, an altercation, 
To cite use Rogers, C (forthcoming), "Life Stories, Criminal Justice and Caring Research." In G, Noblit. [Ed] Oxford Research Encyclopedia of Education, New York, Oxford University Press.

provocation, unfinished business? Girl meets boy, or man in this case really, and men fight. This participant was diagnosed with a personality disorder - well that's okay then, I think?! [...] 'He wanted to kill?' I ask myself. 'Why? What, and now he doesn't want to kill, maim, harm?'. I'm left feeling a little numb - but we hugged out a goodbye and he said he wanted a follow-up (Fieldnotes - Autumn 2016).

The place was dark and dank. There wasn't anywhere to sit. Nowhere to sit. So he suggested we go elsewhere. I wasn't sure where. I was in an unfamiliar area, so I suggested we go to, perhaps go to a coffee shop, or something along those lines. But, what actually happened was he directed me to a car park. We got in my car, and I thought we were going to park in the car park and go somewhere else. A place to carry out the interview. Basically what happened, when I got to his flat he didn't want to stay there because, although he lived alone, he thought someone might hear what he has to say, but given the offences he was going to talk about, the sexual offences (which I didn't know about at that time), he was like 'they weren't very thick walls in the flat' and then when we got in the car, and we were in the car park, I dunno, I just got that feeling he didn't want to go anywhere. He seemed uncomfortable with getting out of the car. And it was a big busy car park, not underground or anything. So I just said, 'well do you want to do the interview here'? He seemed better, happier with that option. And it was really hot, so we had the windows open, but every time someone walked past I put the windows up. As it was obvious he didn't want to speak with people around. Which is fair enough. So even if someone was near, just parking up, then I would do the window up. It was a really long interview. After that, I took him back and dropped him at his flat (Fieldnotes - Spring 2017).

In these instances of violent and/or sexual crimes, I am left with the aftermath of thinking through what occurred, adapting to certain practical situations and emotional responses, and continuing to focus on the research at hand. For these participants, their story, in some cases, was old and in the past. But for me, it was current and in that moment. I have not been trained to deal with these stories. There is no doubt it is emotionally exhausting, and at times I cried about the stories I heard. It has been intense and exhausting as stories fill up my emotional and practical caring spheres. I would like to think I was caring and care-full. However, I am always aware, at times I left the interview space having opened a can of worms.

It is for us, as researchers to understand this process, and commit to ethical and caring practices, for our participants, and our selves. As I can describe here, for example, I spent a minimum of 11 hours with one mother participant (carried out three interviews with her and one with her son). By the time I had visited her for a second and third time her son had returned to prison (had been in and out in between those two interviews), and it seemed inhumane to leave the mother immediately after the interview finished given the emotional content of our discussion. Furthermore, she was alone. Therefore, on both follow-up occasions we went out to lunch after the interview. The last time I visited, on my return I received a positive email, saying 'Lovely to spend time with you today - even though it can be painful it seems also to be cathartic which is good. It really helps talking stuff over with someone who can understand the situation and does not judge. [...] Thank you' (email excerpt, December 2017). She went on to say that the time after the interview 'helps me to "normalise', which became an important part of reflecting upon such emotive data collection and part of a caring research practice I had not anticipated. 
To cite use Rogers, C (forthcoming), "Life Stories, Criminal Justice and Caring Research." In G, Noblit. [Ed] Oxford Research Encyclopedia of Education, New York, Oxford University Press.

\section{Conclusion: A Care Ethics Model - Theoretical and Practical Application to Care-Full Research}

To understand this research process, I turn back to my care ethics model of disability (Rogers, 2016), as it is grounded upon the emotional, practical and socio-political spheres of caring 'work' and is founded upon caring relations within a feminist ethics of care (Robinson 2011, Rogers and Weller 2013, Tronto 1993, 2011). The caring spheres in the model cannot be separated out or completely understood individually. This is because how we respond to 'difficult differences' is emotional, practical and socio-political. The same can be said for our data collection practices, interpretation and theoretical applications. Any 'difficult difference', whether that is between the researcher and participants experiences, responses to a social situation, mental health, or impairment, is important. This caring work carried out is often unconditional and conditional, emotive and practical, and always embedded in the sociopolitical sphere. For example, mother participants in my research have demonstrated inexplicable love and yet professional management as I heard about cries for help and, stories of fighting the system and unimaginable emotional and physical pain. For me, as the researcher, I can demonstrate sadness, care, flexibility, professional integrity, blurred boundaries and political motivation. The emotional, practical and socio-political are constantly leaking into and out of each other during this process. For example, as I have said in the introduction, but it is worth repeating, there are three spheres of caring work (and for the purposes here I am talking about data collection). The Emotional: where love and care are psycho-socially questioned, The Practical: where day to day care is carried out relationally and The Sociopolitical: where social intolerance and aversion to difficult differences are played out. These three spheres all feed into and out of each other during the research process. They are the foundation of a care ethics model of disability and grounded in social and political relations that seek caring legal and cultural processes.

Everyday encounters during data collection can work against caring and care-full practices, where, for example, gate-keepers have the power to include participants or not, personal circumstances are such that telling a story is too challenging, the researcher is emotionally exhausted, the location is potentially risky for all involved, technology fails, and misunderstandings occur. Yet, as is evidenced in this essay, caring research is a process and by being adaptable, reflective and care-full (with both participants and the self), meaningful data is produced, relationships nurtured, and practices improved. Perhaps, within a care ethics model and via the emotional, practical and socio-political spheres we can produce a template for caring research. In the same way as, criminal justice processes struggle with anything that is not about autonomous individuals, research practices can be thwarted when $1+1$ does not $=$ 2. Neither ways are credible when dealing with human beings. Humans are at times, emotional, chaotic and always in relation.

Therefore, rather than simply focusing on the individual and rights-based models, for example within the legal system, where often one person or organisation is pitched against another, we ought to recognise the significance of the relational, and I include research processes here too. After all, caring is a relational practice between two or more people, even if, as a researcher I hear stories about social injustices and violence, for example, a son commits acts of violence against his mother or sends photos of his erect penis to young girls, a man with SEMH rapes a 
To cite use Rogers, C (forthcoming), "Life Stories, Criminal Justice and Caring Research." In G, Noblit. [Ed] Oxford Research Encyclopedia of Education, New York, Oxford University Press.

woman or violently attacks another man, a young woman uses and deals drugs, or a teenage boy sets fire to a building, I must always be caring and suspend judgement, but I ought to care for the self too (and this must include the socio-political, and so the institutions supporting research and knowledge production). Theft, violence, addiction, self-harm and sexual deviance are all part of the narratives I have heard, yet to make changes to criminal justice practices for all affected, not doing this type of research because it might underline potential and unintentional care-less research practices is not a good enough reason to hinder caring research. (see also, Turner and Almack 2017). As highlighted at the beginning of this essay, the $20^{\text {th }}$ Century has seen a mass of research that has uncovered and brought to the public sphere, potentially risqué subjects, such as stories about abuse, drugs, oppression, sexuality and violence (e.g. Becker [1963] 1991, Kelly 1988, Oliver 1990, Plummer 1995, Morris 1991). Doing this type of research has its dilemmas. Yet, if we understand caring relations, while carrying out this research, we will aid a deeper understanding of doing care-full research by clarifying different ways of producing knowledge and grasping how the socio-political, as well as the practical and emotional, merge and facilitate one another. In doing so, we might incite changes that remove oppressive barriers and enable a deeper understanding of hidden lives.

\section{Research support}

The Leverhulme Trust: RF-2016-613\8

\section{References}

Aldridge, J. (2007) 'Picture this: the use of participatory photographic research methods with people with learning disabilities' Disability and Society 22 (1) Pp 1-17.

Allen, R. (2016) 'Young people and prison' in in Y, Jewkes, J, Bennett and B, Crewe, [eds.] Handbook On Prisons (2 ${ }^{\text {nd }}$ Ed.), London, Routledge. Pp 529-548.

Arendt, H. (1998) The Human Condition London, The University of Chicago Press.

Becker, H. S. ([1963] 1991) Outsiders: Studies in the Sociology of Deviance New York, The Free Press.

Becker, H. S. (1967) 'Whose side are we on’ Social Problems 14 (3) Pp 239-247.

Berger, J. (1972) Ways of Seeing London, Penguin Books.

Bradley, K. (2009) 'The Bradley Report', Department of Health, http://webarchive.nationalarchives.gov.uk/20130123195930/http://www.dh.gov.uk/en/Public ationsandstatistics/Publications/PublicationsPolicyAndGuidance/DH_098694

BSA (2017) Statement of Ethical Practice for the British Sociological Association British Sociological Association.

Carrabine, E. (2005) 'Prison Riots, Social Order and the Problem of Legitimacy' The British Journal of Criminology, 45 (6) 1 896-913 
To cite use Rogers, C (forthcoming), "Life Stories, Criminal Justice and Caring Research." In G, Noblit. [Ed] Oxford Research Encyclopedia of Education, New York, Oxford University Press.

Clemson, C. (2015) The Prison Path: School Practices that Hurt Our Youth, Maryland, The Rowman and Littlefield Publishing Group.

Codd, H. (2016) 'Don't you forget about me': Prisoners' Children and Criminal Justice' Inaugural Professorial Lecture held on 14th May 2015 BreakThrough, Winter 2016 http://www.uclan.ac.uk/research/news_and_events/assets/breakthrough-issue-9-winter2016.pdf\#page $=20$

Codd, H. (2008 [2011]) In the Shadow of Prison: Families, imprisonment and criminal justice, London, Routledge

Comfort, M. (2008) Doing time together: love and family in the shadow of the prison Chicago, The University of Chicago Press.

Condry, R. (2007) Families Shamed: The Consequences of Crime for Relatives of Serious Offenders Cullompton, Willan Publishing.

Condry, R., Kotova, A. and Minson, S. (2016) 'Social injustice and collateral damage: The families and children of prisoners' in Y, Jewkes, J, Bennett and B, Crewe, [eds.] Handbook On Prisons ( $2^{\text {nd }}$ Ed.), London, Routledge. Pp 622-640.

Cooper, L. and Rogers, C. (2015) 'Mothering and 'insider' dilemmas: Feminist sociologists in the research process' Sociological Research Online, 20 (2) 5

Copes, H. Tchoula, W. Brookman, F. and Ragland, J. (2018) 'Photo-Elicitation Interviews with Vulnerable Populations: Practical and Ethical Considerations' Deviant Behaviour https://doi.org/10.1080/01639625.2017.1407109 Pp 1-20.

Cowburn, M., Gelshthorpe, L. and Wahidin, A. (2017) (eds.) Research Ethics in Criminology: Dilemmas, Issues and Solutions Abingdon, Routledge.

Farmer, M. (2017) The importance of strengthening prisoners' family ties to prevent reoffending and reduce intergeneration crime London, Ministry of Justice

Fassin, D. (2017) Prison Worlds: An Ethnography of the Carceral Condition Cambridge, Polity Press.

Fish, R. (2018) A Feminist Ethnography of Secure Wards for Women with Learning Disabilities: Locked Away Abingdon, Routledge.

Gillies, V. (2016) Pushed to the edge: Inclusion and behaviour support in schools Bristol, Policy Press.

Gillies, V. and Robinson, Y. (2010) 'Managing emotions in research with challenging pupils', Ethnography and Education 5(1): 97-110.

Gillies, V. and Robinson, Y. (2013) 'At risk pupils and the "caring" curriculum' in C. Rogers and S. Weller (eds.) Critical Approaches to Care: Understanding Caring Relations, Identities and Cultures London, Routledge.

Gilligan, C. (1993) In a Different Voice: Psychological theory and women's development, Cambridge, Mass: Harvard University Press. 
To cite use Rogers, C (forthcoming), "Life Stories, Criminal Justice and Caring Research." In G, Noblit.

[Ed] Oxford Research Encyclopedia of Education, New York, Oxford University Press.

Girling, E (2017) 'Ethical challenges: doing research with children', in M Cowburn, L Gelshthorpe, and A, Wahidin (2017) (eds.) Research Ethics in Criminology: Dilemmas, Issues and Solutions, Abingdon, Routledge.

Halsey, M. and Deegan, S. (2015) “Picking up the pieces': Female significant others in the lives of young (ex) incarcerated males' Criminology and Criminal Justice, 15(2) 131- 151

Hayes, S., Shackell, P. and Mottram, P. (2007) 'The prevalence of intellectual disability in a major UK prison' British Journal of Learning Disabilities 35:162-167.

Held, V. (2006) The Ethics of Care: Personal, Political and Global Oxford, Oxford University Press.

Hoskins, K. (2010) 'The price of success? The experiences of three senior working-class female academics in the UK' Women's Studies International Forum 33 134-140

Hughes, N., Williams, H., Chitsabesan, P., Davies, R., and Mounce, L. (2012) 'Nobody made the connection: The prevalence of neurodisability in young people who offend' London, The office of the Children's Commissioner

Jewkes, Y. Bennett, J. and Crewe, B. (2016) [eds.] $2^{\text {nd }}$ Ed. Handbook on Prisons, London Routledge.

Kelly, L. (1988) Surviving Sexual Violence: Cambridge, Polity Press.

Laming, W. H. (2016). 'In Care, Out of Trouble', London, Prison Reform Trust.

Mahon, R. and Robinson F. (eds.) (2011) Feminist Ethics and Social Policy: Towards a New Global Political Economy of Care, Canada, University of British Columbia Press.

McClimens, A. (2007) 'This is my truth, tell me yours: exploring the internal tensions within collaborative learning disability research' British Journal of Learning Disabilities 36: 271-276

Mills, C. W. (1959) The Sociological Imagination New York, Oxford University Press.

Morris, J. (1991) Pride Against Prejudice: Transforming Attitudes to Disability, London: The Women's Press Ltd.

Noddings, N. (2003) Caring: A Feminine Approach to Ethics and Moral Education London, University of California Press.

Oliver, M. (1990) The Politics of Disablement Houndmills, Palgrave Macmillan.

Plummer, K. (1995) Telling Sexual Stories: Power, Change and Social Worlds London, Routledge.

Plummer, K. (2001) Documents of Life 2: An Invitation to a Critical Humanism London, Sage.

Ribbens, J. and Edwards, R. (1998) (eds) Feminist Dilemmas in Qualitative Research:

Public Knowledge and Private Lives London, Sage Publications 
To cite use Rogers, C (forthcoming), "Life Stories, Criminal Justice and Caring Research." In G, Noblit. [Ed] Oxford Research Encyclopedia of Education, New York, Oxford University Press.

Robinson, F. (2011) The Ethics of Care: A Feminist Approach to Human Security Philadelphia, Temple University Press.

Rogers, C. (2007) Parenting and Inclusive Education: discovering difference, experiencing difficulty Houndmills, Palgrave Macmillan

Rogers, C. (2016) Intellectual Disability and Being Human: A Care Ethics Model London, Routledge

Rogers, C. and Weller, S. (2013) [eds.] Critical Approaches to Care: Understanding caring relations, identities and cultures London, Routledge.

Rogers, C. and Ludhra, G. (2012) 'Research ethics: participation, social difference and informed consent' in S, Bradford and F, Cullen [eds.] Research and Research Methods for Youth Practitioners, London, Routledge.

Rogers, C. (2011) 'Mothering and intellectual disability: partnership rhetoric?' British Journal of Sociology of Education 32 (4) 563-581

Ryan-Flood, R., and Gill, R. (2010) (eds.) Secrecy and Silence in the research process: feminist reflections Oxon, Routledge.

Talbot, J. (2010), 'Seen and Heard: supporting vulnerable children in the youth justice system' London, Prison Reform Trust.

Tronto, J. (1993) Moral Boundaries: A Political Argument for an Ethic of Care London, Routledge.

Tronto, J. (2011) 'A feminist democratic ethics of care and global care workers' in R. Mahon and F. Robinson (eds.) Feminist Ethics and Social Policy: Towards a New Global Political Economy of Care Canada, University of British Columbia Press. Pp. 162-177.

Turner, N. and Almack, K. (2017) 'Recruiting young people to sensitive research: turning the 'wheels within wheels" International Journal of Social Research Methodology 20 (5) Pp. 485497

Wadhwa, A. (2016) Restorative Justice in Urban Schools: Disrupting the School to Prison Pipeline, London, Routledge

Wald, J. and Losen, D. (2007) 'Out of Sight: the journey through the school to prison pipeline' in S. Books (ed.) Invisible Children in the Society and its Schools ( $3^{\text {rd }}$ Ed.) London, Routledge.

Whyte, W. F. ([1943] 1993), Street Corner Society: The social structure of an Italian Slum, London, The University of Chicago Press.

Willis, P ([1978] 1997), Learning to Labor: how working class kids get working class jobs London, Routledge. 
To cite use Rogers, C (forthcoming), "Life Stories, Criminal Justice and Caring Research." In G, Noblit. [Ed] Oxford Research Encyclopedia of Education, New York, Oxford University Press.

Worley, R.M., Worley, V.B., and Wood, B.A. (2016) "There were ethical dilemmas all day long!': harrowing talks of ethnographic researchers in criminology and criminal justice' Criminal Justice Studies, 29 (4) 289-308

\footnotetext{
' Critically, the term 'families' and prisoner families are often used, yet it conceals the gendered care labour that exists, not least of all because the gendered nature of parenting and the ethical, practical and financial implications that persist (c.f. Halsey and Deegan, 2015).
} 